\title{
Target Site Resistance to Acetolactate Synthase Inhibitors in Diplotaxis erucoides and Erucaria hispanica-Mechanism of Resistance and Response to Alternative Herbicides
}

\author{
Maor Matzrafi ${ }^{1,2, * \mathbb{C}}$, Ofri Gerson ${ }^{1}$, Moshe Sibony ${ }^{1}$ and Baruch Rubin ${ }^{1}$ \\ 1 The Robert H. Smith Institute of Plant Sciences and Genetics in Agriculture, Faculty of Agriculture, Food and \\ Environment, The Hebrew University of Jerusalem, PO Box 12, Rehovot 7610001, Israel; \\ ofri.gerson@mail.huji.ac.il (O.G.); moshe.sibony@mail.huji.ac.il (M.S.); rubin@mail.huji.ac.il (B.R.) \\ 2 Department of Plant Pathology and Weed Research, Agricultural Research Organization (ARO), Newe Ya'ar \\ Research Center, P.O. Box 1021, Ramat Yishay 30095, Israel \\ * Correspondence: maorm@volcani.agri.gov.il
}

Received: 8 February 2020; Accepted: 25 March 2020; Published: 29 March 2020

check for updates

\begin{abstract}
Diplotaxis erucoides and Erucaria hispanica are common weeds of the Mediterranean region; they infest various habitats including cultivated fields and roadsides. In several fields across Israel, farmers have reported on poor control of D. erucoides and E. hispanica plants using acetolactate synthase (ALS) inhibitors. Greenhouse experiments were conducted to determine the effect of various ALS inhibitors on plants from two potentially resistant D. erucoides and E. hispanica populations. Additionally, alternative management strategies using auxinic herbicides were studied. Plants from both populations exhibited resistance to all tested ALS inhibitors, up to 20-fold the label field rate, as compared with ALS sensitive populations of D. erucoides and E. hispanica. Sequencing of the ALS gene revealed Trp574 to Leu substitution in ALS-resistant D. erucoides plants, whereas a Pro197 to Ser substitution was detected in ALS-resistant E. hispanica plants. Although high levels of resistance were observed in individuals from both putative resistant populations, sensitive individuals were also detected, suggesting the evolution of resistance in these two populations is still in progress. Auxinic herbicides, 2,4-D, and mecoprop-P, provided excellent control of plants from both ALS-resistant populations. This study documents and confirms the first case of evolution of resistance to ALS inhibitors in D. erucoides and E. hispanica populations.
\end{abstract}

Keywords: alternative management; auxinic herbicides; herbicide resistance; Spanish pink mustard; white wall-rocket

\section{Introduction}

Diplotaxis erucoides (white wall-rocket) and Erucaria hispanica (Spanish pink mustard) are common weeds of the Brassicaceae family spread across the Mediterranean region [1]. These species are frequently found as native weeds mostly in Portugal, Spain, Italy, Cyprus, Greece, Turkey, and Israel; recently, they had also invaded as alien species other countries, such as Romania, Norway, Switzerland, and Slovakia [2]. High germination rate and reproductive success may contribute to the high abundance of these two species [3,4]. Furthermore, both species have high seed fecundity with reproduction mechanisms that prevent self-pollination $[5,6]$. These species can germinate in several flushes in a season, enabling them to better compete with crop seedlings, dominate the entire field, and cause high yield losses (B Rubin, personal communication). The fact that these weed species are exogamous (i.e., they rely mainly on outcross-pollination) may enhance the spread of beneficial adaptive traits, especially if they are inherited as a single dominant gene, such as in the case of target-site resistance [7]. 
Acetolactate synthase (ALS) inhibiting herbicides (group B, HRAC/WSSA) are the main mode of action (MOA) used for selective weed control in crops [8,9]. With more than 50 known active ingredients, this MOA can be used almost in every crop; thus, herbicide rotations are often neglected [10]. Five different chemical groups are known as ALS inhibitors: sulfonylurea (SU), imidazolinone (IMI), triazolopyrimidine (TP), pyrimidiny-lthiobenzoate (PTB), and sulfonyl-aminocarbonyl-triazolinone (SCT) [10].

The evolution of resistance to photosystem II (PSII) inhibiting herbicides (group C) has resulted in a dramatic increase in the use of ALS inhibitors in agricultural and non-agricultural areas [11]. This over-use across all types of habitats resulted in a fast increase in the number of cases of evolved resistance and even lead to the evolution of multiple-herbicide resistance species [12]. Mechanisms of resistance to ALS inhibitors in weeds typically involve an altered target site [13]. Different mutations and substitutions may result in various levels of resistance to ALS inhibitors [14]. Generally, the evolution of an herbicide resistance trait is associated with a fitness cost to the individuals showing the trait when the selective factor (herbicide) is removed from the environment, thus the frequency of such mutations is presumed to be very low [15]. However, in most cases, target-site resistance to ALS inhibitors does not carry a fitness penalty [16]. Resistance to ALS inhibitors can also be endowed by non-target site mechanisms as reviewed by Délye (2013). This type of ALS-resistance was reported in Sinapis arvensis L. [17] and Papaver rhoeas [18], as well as in plants showing multiple-resistance with other modes of action, such as glyphosate and ACCase-inhibitors [19].

In Israeli dry-land farming, wheat (Triticum aestivum) and pea (Pisum sativum) are the main crops. Two common three-year crop rotations are traditionally in practice: (i) the main rotation is wheat/wheat/fallow, where SU, TP, or SCT herbicides are mainly used; and (ii) the minor one is wheat/peas/wheat where IMI herbicides are used in peas, and SU, PTB, or SCT are commonly used in wheat.

Recently, farmers have reported on poor control of D. erucoides and E. hispanica plants using ALS-inhibitors. We suggest that the intensive use of ALS inhibitors in both rotations resulted in the evolution of ALS-resistant individuals. The aim of this study was to (1) confirm ALS resistance in two potentially resistant $D$. erucoides and E. hispanica populations and (2) to elucidate the mechanism of resistance. Moreover, (3) we tested the use of auxinic herbicides (Group O) as an alternative management practice, in preventing further buildup of ALS-resistant weed populations.

\section{Materials and Methods}

\subsection{Plant Material}

Seeds of two potentially resistant populations of D. erucoides (DER) and E. hispanica (EHR) were

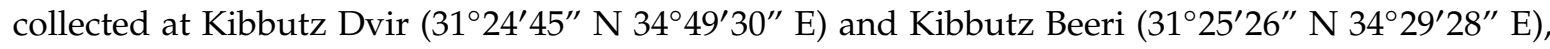
respectively. Samples were collected from fields (20-30 hectares) where farmers reported on weed control failure using ALS inhibitors. Seeds of sensitive populations of D. erucoides (DES) and E. hispanica (EHS) were collected from an uncultivated area where no herbicides have been used at Kibbutz Re'em $\left(31^{\circ} 23^{\prime} 08^{\prime \prime} \mathrm{N} 34^{\circ} 27^{\prime} 34^{\prime \prime} \mathrm{E}\right)$. To ensure appropriate representation of field population, mature seedpods from 30 to 40 randomly selected plants in each population were collected and pooled. Collected seeds were air-dried and stored at $4{ }^{\circ} \mathrm{C}$ until used. Seeds from each population were germinated in flats filled with commercial potting media (Tuff, Marom Golan, Israel), including Osmocote®(The Scotts Company, Marysville, OH, USA) slow release fertilizer. Seedlings of D. erucoides and E. hispanica populations at the fully developed cotyledons stage were transplanted into pots, 7 by 7 by $6 \mathrm{~cm}$ (one plant per pot), filled with the same potting media. Pots were kept in a greenhouse $\left(22 / 16^{\circ} \mathrm{C}\right.$, day/night), at natural light conditions, and watered daily. 


\subsection{Plant Responses to ALS Herbicides}

At the stage of three to four true leaves, plants were treated with $0,1 / 32,1 / 16,1 / 8,1 / 41 / 2,1,2$, or 4 times the label field rate of each ALS inhibiting herbicides using a chain-driven sprayer delivering $300 \mathrm{~L} \mathrm{ha}^{-1}$, with a flat-fan $8001 \mathrm{E}$ nozzle (TeeJet $\AA$, Spraying Systems Co., Wheaton, IL, USA). Different ALS inhibitors (commercial formulations) and their label field rate are detailed in Table 1. The level of resistance in both DER and EHR populations was determined in a separate experiment when plants from all populations were treated with high rates of 10 and 20 times the label field rate of each herbicide as previously described. All experiments were arranged in a completely randomized-factorial design, with three to five replicates for each treatment, and repeated three times. No significant treatment by experimental run were observed; therefore, the data obtained from the repeated experiments for each herbicide were pooled. Shoot fresh weight (FW) and survival rate (alive or dead) were recorded 21 days after treatment (DAT).

Table 1. Herbicides used in this study. ALS = acetolactate synthase; MOA = mode of action; $\mathrm{SU}=$ sulfonylureas; $\mathrm{IMI}=$ imidazolinones; TP = triazolopyrimidines; $\mathrm{SCT}$ = sulfonylaminocarbonyltriazolinones.

\begin{tabular}{|c|c|c|c|c|c|}
\hline MOA & Common Name & $\begin{array}{c}\text { ALS Chemical } \\
\text { Family }\end{array}$ & Trade Name & $\begin{array}{c}\text { Label Field } \\
\text { Rate }\left(\mathrm{g} \text { ai ha }{ }^{-1}\right)\end{array}$ & Manufacturer \\
\hline \multirow{4}{*}{ ALS Inhibitors } & Tribenuron-methyl & SU & Express $囚$ & 15 & DuPont \\
\hline & Imazamox & IMI & Pulsar® & 24 & BASF \\
\hline & Florasulam & $\mathrm{TP}$ & Darbukaß & 4 & ADAMA-Agan \\
\hline & Propoxycarbazone-sodium & SCT & Olympus® & 45.5 & Bayer \\
\hline Auxinic & $2,4-\mathrm{D}$ & & Albar Super $®$ & 670 & ADAMA-Makhteshim \\
\hline Herbicides & Mecoprop-P & & Duplosan® & 1200 & Nufarm \\
\hline
\end{tabular}

\subsection{Plant Responses to Auxinic Herbicides}

At the stage of three to four true leaves, plants from both DER and EHR populations were treated with two different auxinic herbicides, as detailed in Table 1. Each of the auxinic herbicides was applied at the following rates: $1 / 4,1 / 2,1,2$, or 4 times the label field rate as described above. The experiment was arranged in a completely randomized-factorial design, with three to five replicates of each treatment and was repeated three times. No significant treatment by experimental run were observed; therefore, the data obtained from the repeated experiments for each herbicide were pooled. Shoot FW and survival rate (alive or dead) were recorded 21 DAT.

\subsection{DNA Extraction and Molecular Studies}

Leaf tissue $\left(3 \mathrm{~cm}^{2}\right)$ was excised from individual plants of all four populations (DER, EHR, DES, and EHS). Each sample was placed separately in a microtube. DNA was extracted using the Puregene DNA isolation kit (Gentra Systems, Minneapolis, MN, USA) according to the manufacturer's instructions and diluted 10-fold before further use. Specific primers were used to identify the ALS gene and locate common point mutations previously shown to endow resistance to ALS inhibitors. Primers were designed according to the known sequences of the ALS genes from Arabidopsis thaliana (X51514) and Lolium rigidum (DQ184640.1) (Table 2). Sequence analyses and alignment were performed using the Bioedit software [20]. The obtained sequences were compared to the known sequence of the ALS gene of A. thaliana (X51514). 
Table 2. Primers used for PCR and sequencing reactions.

\begin{tabular}{|c|c|c|c|c|}
\hline \multirow{2}{*}{ Primers } & \multirow{2}{*}{ Sequence $\left(5^{\prime}-3^{\prime}\right)$} & \multirow{2}{*}{ Position } & Product & \multirow{2}{*}{ Reference } \\
\hline & & & Size (bp) & \\
\hline ALS-A F & GCTGATATCCTCGTCGAAGC & \multirow{2}{*}{$122,197,205$} & \multirow[t]{2}{*}{490} & \multirow{6}{*}{$\begin{array}{l}\text { Arabidopsis thaliana }(X 51514) \text { and } \\
\text { Lolium rigidum }(D Q 184640.1)\end{array}$} \\
\hline ALS-A R & GAATCGGAAGCTGTTGA & & & \\
\hline ALS-B F & CGCTGTTGATAAGGCTGACC & \multirow[t]{2}{*}{$376,377,574$} & \multirow[t]{2}{*}{800} & \\
\hline ALS-B R & ACAAGTATGGCCCAGGAGTC & & & \\
\hline ALS-C F & AAGTACTGGTGTCGGGCAAC & \multirow{2}{*}{$574,653,654$} & \multirow{2}{*}{500} & \\
\hline ALS-C R & GGCAACACATGTTCTGGTG & & & \\
\hline
\end{tabular}

F-forward, and R-reverse primers.ALS-A, B and C-first, second and third fragment of the ALS gene sequence.

\subsection{Statistical Analyses}

Data of FW were analyzed using ANOVA in JMP (ver. 13) statistical package (SAS Institute Inc., Cary, NC, USA) as the percentage of FW reduction compared to the untreated control. Means were compared using Student's $t$-test $(\alpha=0.05)$. Dose-response curve experiments were conducted to evaluate the effect of different herbicides on the average shoot FW and survival rate of plants from each population. For each treatment, data is presented and plotted as a percentage of untreated control. Data were fit to a nonlinear sigmoidal logistic three-parameter model [21] as described in Equation (1):

$$
Y=\frac{a}{1+\left(\frac{x}{X o}\right)^{b}} .
$$

In this model, if $b>0$, then $a$ describes the upper limit of $Y ; X_{0}$ describes the herbicide rate causing $50 \%$ shoot FW reduction $\left(\mathrm{ED}_{50}\right)$ or $50 \%$ mortality $\left(\mathrm{LD}_{50}\right)$, and $b$ describes the slope of the curve. For each species, the resistance index (RI) was calculated as the R: S (resistant: susceptible) ratio.

\section{Results and Discussion}

\subsection{Response to ALS Iinhibitors}

Although they are very common in the Mediterranean region, apart from this case, herbicide resistance has never before been reported for both D. erucoides or E. hispanica [9]. Plants from the DER population exhibited resistance in response to imazamox, propoxycarbazone-sodium, and tribenuron-methyl (RI > 10). EHR plants, were highly resistant to all tested ALS inhibitors except imazamox (Table 3; Figures 1 and 2). A wide range of herbicide responses among DER and EHR populations were recorded, including highly resistant, as well as highly sensitive individuals were found in both populations. This was mainly pronounced in imazamox-treated DER plants and tribenuron-methyl treated EHR plants, as increasing rates did not show the same response as some of the lower rates did (Figure 1b). No significant reduction in FW and survival percentage of EHR plants was recorded in response to tribenuron-methyl; thus, the $\mathrm{ED}_{50}$ and $\mathrm{LD}_{50}$ values have exceeded the highest applied rate $\left(60 \mathrm{~g} \mathrm{ha}^{-1}\right)$, which eventually resulted in failure to fit a correct model to describe this treatment (Figure 2a). 
Table 3. Effects of post-emergence treatments on the shoot fresh weight (FW) of plants from D. erucoides (DES) and E. hispanica (EHS) ALS-sensitive and -resistant populations (DES, D. erucoides (DER), EHS, and E. hispanica (her), respectively). Herbicides were applied at 1 and 4 times the label field rate (X).

\begin{tabular}{|c|c|c|c|c|c|c|c|c|c|c|c|c|c|c|c|c|}
\hline \multirow{3}{*}{ Pop' } & \multicolumn{16}{|c|}{ Shoot FW (\% of untreated control) } \\
\hline & \multicolumn{3}{|c|}{ Imazamox $^{a}$} & \multicolumn{4}{|c|}{ Propoxycarbazone-Sodium $^{\text {b }}$} & \multicolumn{4}{|c|}{ Tribenuron-methyl ${ }^{\mathrm{c}}$} & \multirow[b]{2}{*}{ RI } & \multicolumn{4}{|c|}{ Florasulam $^{\mathrm{d}}$} \\
\hline & $x$ & $4 X$ & $\mathrm{ED}_{50}$ & RI & $x$ & $4 X$ & $\mathrm{ED}_{50}$ & RI & $\mathrm{x}$ & $4 X$ & $\mathrm{ED}_{50}$ & & $\mathrm{x}$ & $4 X$ & $\mathrm{ED}_{50}$ & RI \\
\hline DER & $21 \pm 40$ & $16 \pm 31$ & 23.7 & & $24 \pm 10^{*}$ & $17 \pm 7 *$ & 14.5 & 72.5 & $47 \pm 19^{*}$ & $25 \pm 17$ & 3.4 & 85 & $20 \pm 24$ & $31 \pm 31$ & 1 & 5 \\
\hline DES & $0.2 \pm 0.1$ & $0.2 \pm 0.1$ & 1.7 & 14 & $1.7 \pm 0.3$ & $0.9 \pm 0.4$ & 0.2 & & $1.5 \pm 1$ & $2.6 \pm 0.7$ & 0.04 & & $0.6 \pm 0.9$ & $0.16 \pm 0.1$ & 0.2 & \\
\hline EHR & $51 \pm 12 * *$ & $22 \pm 31$ & 28.5 & 7 & $55 \pm 33^{*}$ & $31 \pm 27^{*}$ & 55.9 & 69.8 & $128 \pm 35^{* *}$ & $57 \pm 64$ & $>60$ & $>60$ & $106 \pm 31$ ** & $47 \pm 55$ & 14.4 & 24 \\
\hline EHS & $2 \pm 1.3$ & $0.2 \pm 0.2$ & 4.1 & 7 & $0.9 \pm 1.1$ & $0.5 \pm 0.3$ & 0.8 & & $1.3 \pm 0.3$ & $0.1 \pm 0.1$ & 0.4 & & $2.6 \pm 2.7$ & $0.2 \pm 0.1$ & 0.6 & \\
\hline
\end{tabular}

$\mathrm{ED}_{50}$ value represent herbicide rate reducing plant growth by $50 \%$ were extracted from the dose response curves. RI was calculated as the ratio of the $\mathrm{ED}_{50}$ value of the resistant population compared with the $\mathrm{ED}_{50}$ of the sensitive one. Each comparison was between a resistant and sensitive population from the same species under the same treatment. * or ** asterisks indicate on significant differences between treatments, as determined using Student $t$ test $(P \leq 0.05$ and 0.01$)(n=12)$. Label field rate for each herbicide $(\mathrm{X}){ }^{\mathrm{a}} 24 \mathrm{~g}$ ai ha ${ }^{-1}, \mathrm{~b} 45.5 \mathrm{~g}$ ai ha ${ }^{-1},{ }^{\mathrm{c}} 15 \mathrm{~g}$ ai $\mathrm{ha}^{-1}$, and ${ }^{\mathrm{d}} 4 \mathrm{~g}$ ai ha ${ }^{-1}$. 

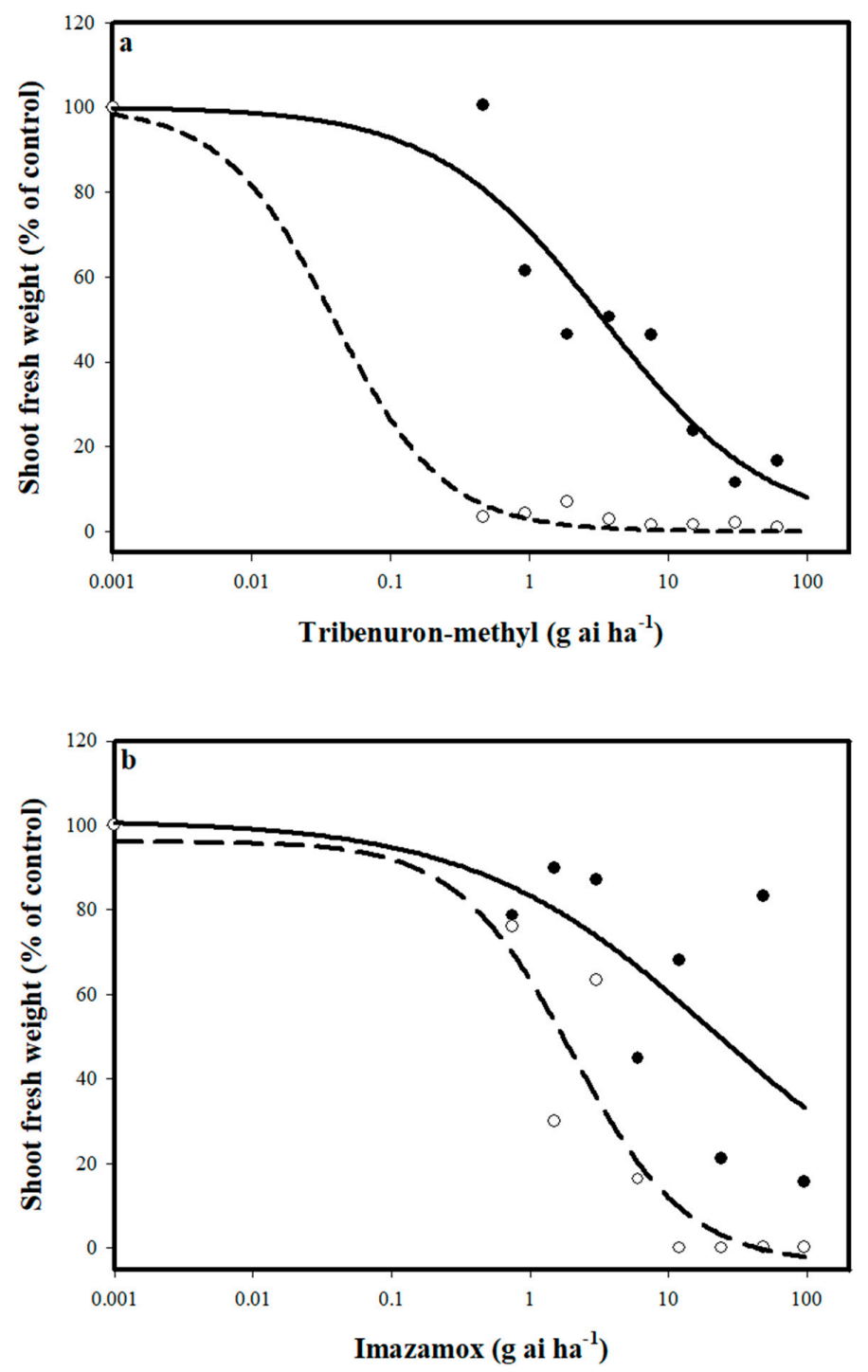

Figure 1. Effects of tribenuron-methyl (a) and imazamox (b) applied post-emergence at increasing rates on the shoot fresh weight of $\mathrm{S}$ (open circles) and $\mathrm{R}$ (closed circles) populations of Diplotaxis erucoides. Data was collected 21 days after treatment.

The fact that both resistant populations (DER and EHR) exhibited high level of variability in the response to ALS inhibitors may indicate that these populations are still in transition, comprising a mixture of resistant and sensitive individuals. The data concerning survival rates show that even though shoot fresh weight was not significantly different from sensitive populations (DES and EHS), more than $25 \%$ of plants from both resistant populations survived the highest rate (4X) of all four ALS inhibitors (Table 4). When treated with the highest rate of tribenuron-methyl, DER showed a higher survival rate than $\mathrm{EHR}$; however, $\mathrm{LD}_{50}$ values of both populations exceeded the highest rate (>60). In contrast, EHR had higher survival rates following treatment with imazamox, as presented also by higher $\mathrm{LD}_{50}$ values (36.67 vs. 19.42; Table 4). When both sets of data (shoot FW and survival rate) are viewed side by side, it appears that the DER and EHR populations are at a transitional stage and have not yet developed homogenic response to the tested ALS inhibitors. Using high herbicide rates, 10 and 20 times the label field rate, we have detected high number of survivors in both species alongside susceptible individuals (data not shown), reinforcing our hypothesis that the evolution of resistance to ALS inhibitors in these two populations is still in progress. Previous studies on D. erucoides or E. hispanica mainly deal with their ecological traits and adaptation ability to thrive in different 
environments $[3,4,6,22]$. These highly adaptive traits emphasize the risk in the evolution of herbicide resistance of these two species.
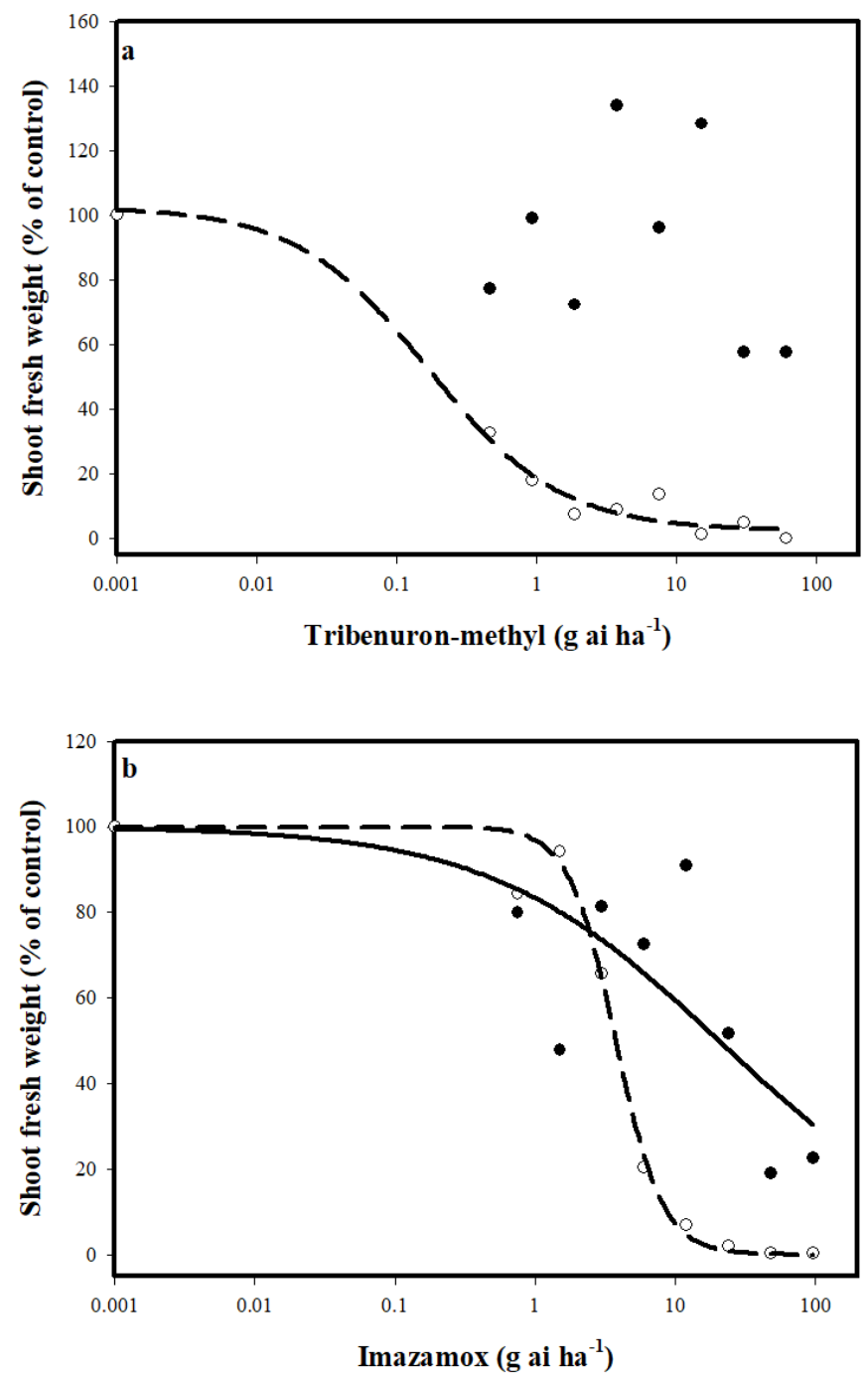

Figure 2. Effects of tribenuron-methyl (a) and imazamox (b) applied post-emergence at increasing rates on the shoot fresh weights of $S$ (open circles) and R (closed circles) Erucaria hispanica populations. Data was collected 21 days after treatment.

Table 4. Effects of post-emergence treatments on the survival rate of plants from D. erucoides and E. hispanica ALS-sensitive and -resistant populations (DES, DER, EHS, and EHR, respectively). Herbicides were applied at 1 and 4 times the label field rate $(X)$.

\begin{tabular}{|c|c|c|c|c|c|c|c|c|c|c|c|c|c|c|c|c|}
\hline \multirow{3}{*}{9} & \multicolumn{16}{|c|}{ Survival (\%) } \\
\hline & \multicolumn{4}{|c|}{ Imazamox ${ }^{a}$} & \multicolumn{4}{|c|}{$\underset{b}{\text { Propoxycarbazone-sodium }}$} & \multicolumn{4}{|c|}{ Tribenuron-methyl $^{\mathrm{c}}$} & \multicolumn{4}{|c|}{ Florasulam $^{\mathrm{d}}$} \\
\hline & $X$ & $4 X$ & $\mathrm{LD}_{50}$ & RI & $X$ & $4 X$ & $\mathrm{LD}_{50}$ & RI & $X$ & $4 X$ & $\mathrm{LD}_{50}$ & RI & $X$ & $4 X$ & $\mathrm{LD}_{50}$ & RI \\
\hline DER & 50 & 25 & 70.30 & & 50 & 50 & 69.93 & & 100 & 75 & $>60$ & & 50 & 75 & 132.17 & \\
\hline DES & 0 & 0 & 3.62 & 19.42 & 0 & 0 & 0.002 & $>182$ & 0 & 0 & 0.01 & $>60$ & 0 & 0 & 1.02 & $>16$ \\
\hline EHR & 100 & 33 & 93.82 & 2667 & 100 & 50 & 50.00 & & 100 & 50 & 62.45 & & 100 & 75 & $>16$ & \\
\hline EHS & 0 & 0 & 2.85 & 36.67 & 0 & 0 & 0.002 & & 0 & 0 & 0.70 & $>60$ & 0 & 0 & 0.69 & $>16$ \\
\hline
\end{tabular}

$\mathrm{LD}_{50}$ value represent herbicide rate reducing survival rate by $50 \%$ were extracted from the dose response curves. $\mathrm{RI}$ was calculated as the ratio of the $\mathrm{LD}_{50}$ value of the resistant population compared with the $\mathrm{LD}_{50}$ of the sensitive one. Label field rate for each herbicide: ${ }^{\mathrm{a}} 24 \mathrm{~g}_{\mathrm{ai} \mathrm{ha}}{ }^{-1} \mathrm{~b}^{\mathrm{b}} 45.5 \mathrm{~g}$ ai ha ${ }^{-1},{ }^{\mathrm{c}} 15 \mathrm{~g}$ ai ha ${ }^{-1}$, and ${ }^{\mathrm{d}} 4 \mathrm{~g}$ ai ha ${ }^{-1}$. 


\subsection{Mechanism of Resistance to ALS Inhibitors}

Several different $A L S$ gene point mutations have been previously identified to endow resistance to ALS inhibitors [14]. Specific point mutation may alter plant response to ALS inhibitors, as will different amino acid substitutions at the same point mutation [23].

Alignment of sequences from DER plants revealed a Trp574 to Leu substitution in the ALS gene sequence (Figure 3a). In EHR plants, a different substitution, Pro197 to Ser was detected (Figure 3b). To better understand mutations rate and their nature (homozygous and heterozygous) in both DER and EHR populations, random individuals from each population were sequenced. In the DER population, the homozygous (R/R) form of the Trp574 to Leu substitution was found in four out of 15 individuals, two of these individuals exhibited heterozygosity $(\mathrm{R} / \mathrm{S})$ and the rest were homozygous for the ALS-sensitive allele (S/S). Out of 12 individual plants from the EHR population, six were found to be homozygous (R/R) for the Pro197 to Ser substitution, four exhibited heterozygosity (R/S), and two were homozygous for the ALS-sensitive allele (S/S). Differences in allelic frequency between both resistant populations can also be correlated with the variation in response to ALS inhibitors. In most studies, mutations in Trp574 confers high level of resistance to all ALS inhibitors [24-27], while mutations in position Pro197 are mainly associated with high level of resistance to SU herbicides [18,28,29]. The fact that resistance to IMI and SCT herbicides was higher in DER, while resistance to SU was higher in EHR can be associated with the different target site mutations detected in the ALS gene sequence of plants from both populations. It can be suggested that the observed differences in resistance levels and the abundance of mutations are characteristic of a weed population in a transitional stage toward homogenic resistance.

a

Arabidopsis thaliana X51514.1
Diplotaxis erucoides (DES)
Diplotaxis erucoides (DER)
Diplotaxis erucoides (DER)

b

Arabidopsis thaliana X51514.1

Erucaria hispanica (EHS)

Erucaria hispanica (EHR)

Erucaria hispanica (EHR)
570

580

$\ldots . \ldots .|\ldots| \ldots|\ldots| \ldots \mid$. .

LLLNNQHLGMVMQWEDRFYKANRAHT

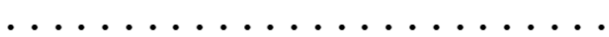

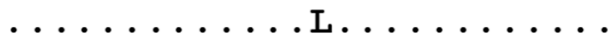

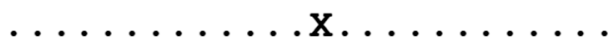

190

200

$\ldots|\ldots| \ldots|\ldots| \ldots \mid$. DALLDSVPLVAITGQVPRRMIGTDA

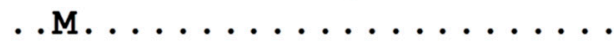

$\ldots \mathrm{M} \ldots \ldots \ldots \ldots \mathrm{s} \ldots \ldots$.

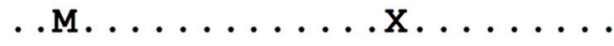

Figure 3. Alignment of partial ALS gene sequence of plants from $\mathrm{S}$ and R populations of Diplotaxis erucoides and Erucaria hispanica (DES, DER, EHS, and EHR, respectively). Amoni acid substitutions of Trp574 to Leu in DER plants (a) and Pro197 to Ser in EHR plants (b). Positions refer to the known ALS gene sequence of $A$. thaliana (X51514).

\subsection{Alternative Management Using Auxinic Herbicides}

Several chemicals that confer auxinic activity are used as herbicides [30]. Epinasty, shoot reorientation, curly leaf, and early senescence have been documented as plant response to auxinic herbicide activity [31,32]. When treated with auxinic herbicides, 2,4-D, or mecoprop-P, ALS-resistant D. erucoides and E. hispanica plants were severely and rapidly damaged, and no survivors were detected at any tested rate. Even at the rate of $1 / 4 X$, none of the treated plants survived (Figure 4). Auxinic herbicides may be used to control ALS-resistant individuals to contain and reduce the problem we currently face, preventing further buildup of resistance, such as in the case of Raphanus raphanistrum [33] in Australia, Kochia scoparia [34] in Western Canada, and Amaranthus tuberculatus [35] in the USA. 
To reduce the probability of evolution of resistance to auxinic herbicides, proper crop rotation, as well as other components of integrated weed management, should be applied.

a
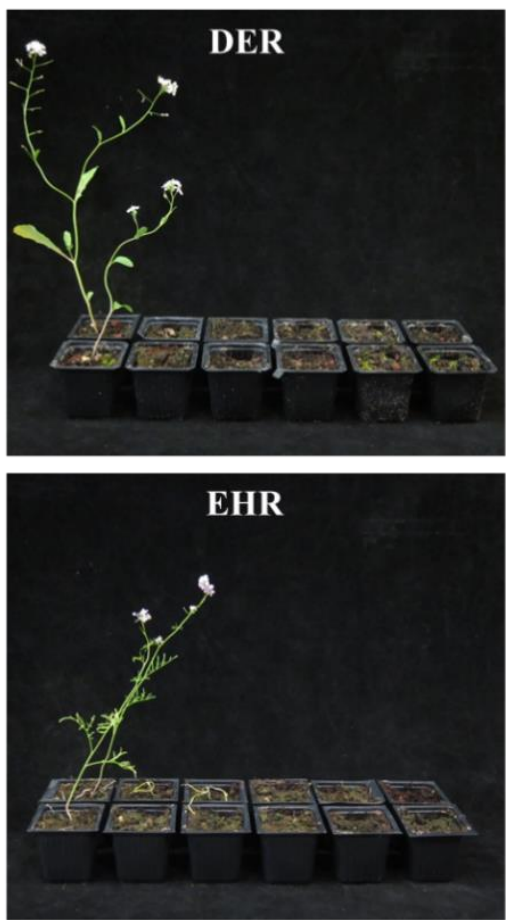

$0 \quad 16733567013402680$ b
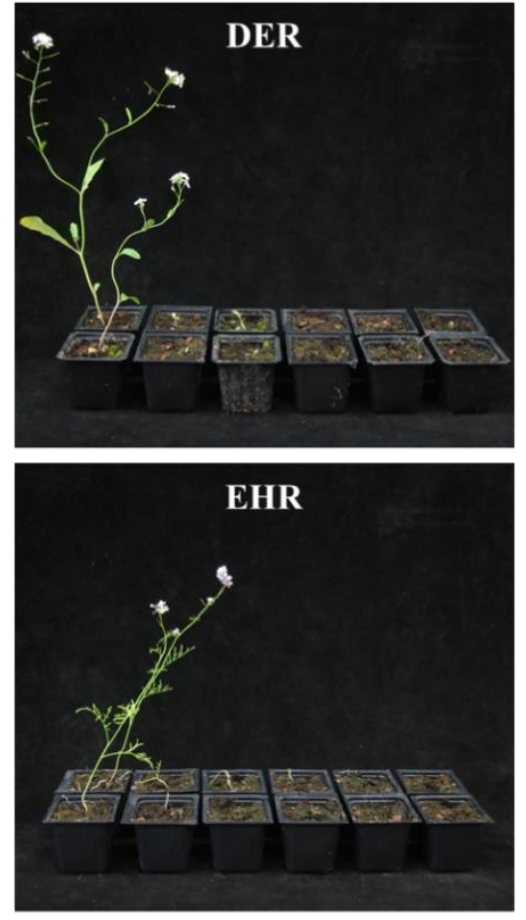

$0 \quad 300600120024004800$

Mecoprop-P g ai ha ${ }^{-1}$

Figure 4. Effect of increasing rates of two auxinic herbicides on survival and shoot fresh weight of plants from D. erucoides (DER) and E. hispanica (EHR) ALS-resistant populations. Recommended rate for Mecoprop-P (a) and 2,4-D (b) are 670 and $1200 \mathrm{~g}_{\text {ai ha }}{ }^{-1}$, respectively.

As was shown before, the over-use of one herbicide can eventually lead to resistance to several other herbicides from the same MOA [36,37]. According to the records of herbicide applications received from the farmers, extensive and prolonged use of tribenuron-methyl and iodosulfuron was documented in fields were DER and EHR populations were found. The evolution of ALS-resistant populations of D. erucoides and E. hispanica in pea and wheat fields may be associated with the repeated use of ALS inhibitors.

\section{Conclusions}

Populations of D. erucoides and E. hispanica collected from pea and wheat fields were found to be resistant to ALS inhibitors. In both populations, resistance was found to be associated with target site mutations in the ALS gene sequence. Auxinic herbicides provided excellent control of plants from both ALS-resistant populations. According to the record of herbicide applications received from the farmers, ALS inhibitors have been extensively used in these fields, which in turn may explain the evolution of resistance to ALS inhibitors. Different resistance levels may suggest these populations are in a transitional stage toward homogenic resistance. This report should increase the awareness and alert farmers and researchers in the region and beyond in order to proactively challenge the evolution of herbicide resistance in D. erucoides and E. hispanica in arable crops.

Author Contributions: Conceptualization, M.M. and B.R.; Data curation, M.M. and O.G.; Formal analysis, M.M. and O.G.; Methodology, M.M., M.S. and B.R.; Visualization, M.M.; Writing-original draft, M.M. and B.R.; 
Writing-review \& editing, M.M., O.G., M.S. and B.R. All authors have read and agreed to the published version of the manuscript.

Funding: This research received no external funding.

Acknowledgments: The authors would like to thank Tom Kliper and Ziv Kleinman for their technical assistance. First (M.M.) and second (O.G.) authors are the recipient of scholarships from the Teomim Foundation, the Natan Yaffe Foundation and the Zion Cohen Foundation.

Conflicts of Interest: The authors declare no conflict of interest.

\section{References}

1. Danin, A. Flora of Israel Online. Available online: http://www.flora.huji.ac.il (accessed on 1 December 2019).

2. Marhold, K. Brassicaceae. Euro + Med Plantbase - the Information Resource for Euro-Mediterranean Plant Diversity. 2014. Available online: http://www.bgbm.org/EuroPlusMed/query.asp (accessed on 1 December 2019).

3. Aronson, J.; Kigel, J.; Shmida, A.; Klein, J. Adaptive phenology of desert and Mediterranean populations of annual plants grown with and without water stress. Oecologia 1992, 89, 17-26. [CrossRef]

4. Perez-Garcia, F.; Iriondo, J.M.; Martinezn-Laborde, J.B. Germination behaviour in seeds of Diplotaxis erucoides and D. virgata. Weed Res. 1995, 35, 495-502. [CrossRef]

5. Kunin, W.E. Density and reproductive success in wild populations of Diplotaxis erucoides (Brassicaceae). Oecologia 1992, 91, 129-133. [CrossRef] [PubMed]

6. Boaz, M.; Piltman, U.; Heyn, C.C. Reproductive effort in desert versus mediterranean crucifers: The allogamous Erucaria rostrata and E. hispanica and the autogamous Erophila minima. Oecologia 1994, 100, 286-292. [CrossRef]

7. Délye, C.; Jasieniuk, M.; Le Corre, V. Deciphering the evolution of herbicide resistance in weeds. Trends Genet. 2013, 29, 649-658. [CrossRef]

8. Brown, H.M. Mode of action, crop selectivity, and soil relations of the sulfonylurea herbicides. Pestic. Sci. 1990, 29, 263-281. [CrossRef]

9. Duggleby, R.G.; McCourt, J.A.; Guddat, L.W. Structure and mechanism of inhibition of plant acetohydroxyacid synthase. Plant Physiol. Biochem. 2008, 46, 309-324. [CrossRef]

10. Heap, I. The International Survey of Herbicide Resistant Weeds. Available online: http://www.weedscience. com (accessed on 1 December 2019).

11. Rubin, B.; Yaacoby, T.; Schonfeld, M. Triazine resistant grass weeds: Cross resistance with wheat herbicide, a possible threat to cereal crops. In Proceedings of the British Crop Protection Conference-Weeds, Brighton, UK, 18-21 November 1985; pp. 1171-1178.

12. Sibony, M.; Rubin, B. Molecular basis for multiple resistance to acetolactate synthase-inhibiting herbicides and atrazine in Amaranthus blitoides (prostrate pigweed). Planta 2003, 216, 1022-1027. [CrossRef]

13. Heap, I. Global perspective of herbicide-resistant weeds. Pest Manag. Sci. 2014, 70, 1306-1315. [CrossRef]

14. Tranel, P.J.; Wright, T.R.; Heap, I. ALS mutations from herbicide-resistant weeds. Available online: http: //www.weedscience.com (accessed on 1 December 2019).

15. Rubin, B.; Tal, A.; Yasuor, H. The significance and impact of herbicide resistance weeds-A global overview. Acta Herbol. 2004, 13, 277-288.

16. Yu, Q.; Han, H.; Vila-aiub, M.M.; Powles, S.B. AHAS herbicide resistance endowing mutations: Effect on AHAS functionality and plant growth. J. Exp. Bot. 2010, 61, 3925-3934. [CrossRef] [PubMed]

17. Veldhuis, L.J.; Hall, L.M.; O’Donovan, J.T.; Dyer, W.; Hall, J.C. Metabolism-based resistance of a wild mustard (Sinapis arvensis L.) biotype to ethametsulfuron-methyl. J. Agric. Food Chem. 2000, 48, 2986-2990. [CrossRef] [PubMed]

18. Rey-Caballero, J.; Menéndez, J.; Osuna, M.; Salas, M.; Torra, J. Target-site and non-target-site resistance mechanisms to ALS inhibiting herbicides in Papaver rhoeas. Pestic. Biochem. Physiol. 2017, 138, 57-65. [CrossRef] [PubMed]

19. Yu, Q.; Abdallah, I.; Han, H.; Owen, M.; Powles, S. Distinct non-target site mechanisms endow resistance to glyphosate, ACCase and ALS-inhibiting herbicides in multiple herbicide-resistant Lolium rigidum. Planta 2009, 230, 713-723. [CrossRef] [PubMed]

20. Hall, T.A. BioEdit: A user-friendly biological sequence alignment editor and analysis program for Windows 95/98/NT. Nucleic Acids Symp. Serious 1999, 41, 95-98. 
21. Seefeldt, S.S.; Jensen, J.E.; Fuerst, E.P. Feature log-logistic analysis of herbicide dose-response relationships. Weed Technol. 1995, 9, 218-227. [CrossRef]

22. Korboulewsky, N.; Bonin, G.; Massiani, C. Biological and ecophysiological reactions of white wall rocket (Diplotaxis erucoides L.) grown on sewage sludge compost. Environ. Pollut. 2002, 117, 365-370. [CrossRef]

23. Han, H.; Yu, Q.; Purba, E.; Li, M.; Walsh, M.; Friesen, S.; Powles, S.B. A novel amino acid substitution Ala-122-Tyr in ALS confers high-level and broad resistance across ALS-inhibiting herbicides. Pest Manag. Sci. 2012, 1164-1170. [CrossRef]

24. Boutsalis, P.; Karotam, J.; Powles, S.B. Molecular basis of resistance to acetolactate synthase-inhibiting herbicides in Sisymbrium orientale and Brassica tournefortii. Pestic. Sci. 1999, 516, 507-516. [CrossRef]

25. Scarabel, L.; Varotto, S.; Sattin, M. A European biotype of Amaranthus retroflexus cross-resistant to ALS inhibitors and response to alternative herbicides. Weed Res. 2007, 47, 527-533. [CrossRef]

26. Matzrafi, M.; Lazar, T.W.; Sibony, M.; Rubin, B. Conyza species: Distribution and evolution of multiple target-site herbicide resistances. Planta 2015, 242, 259-267. [CrossRef] [PubMed]

27. Tan, M.; Medd, R. Characterisation of the acetolactate synthase (ALS) gene of Raphanus raphanistrum L. and the molecular assay of mutations associated with herbicide resistance. Plant Sci. 2002, 163, 195-205. [CrossRef]

28. Kaloumenos, N.S.; Eleftherohorinos, I.G. Identification of a johnsongrass (Sorghum halepense) biotype resistant to ACCase-inhibiting herbicides in Northern Greece. Weed Technol. 2009, 23, 470-476. [CrossRef]

29. Cruz-Hipolito, H.; Rosario, J.; Ioli, G.; Osuna, M.D.; Smeda, R.J.; González-Torralva, F.; De Prado, R. Resistance mechanism to tribenuron-methyl in white mustard (Sinapis alba) from Southern Spain. Weed Sci. 2013, 61, 341-347. [CrossRef]

30. Grossmann, K. Auxin herbicides: Current status of mechanism and mode of action. Pest Manag. Sci. 2010, 66, 113-120. [CrossRef]

31. Watahiki, M.K.; Yamamoto, K.T. The massugu1 mutation of Arabidopsis identified with failure of auxin-induced growth curvature of hypocotyl confers auxin insensitivity to hypocotyl and leaf. Plant Physiol. 1997, 115, 419-426. [CrossRef]

32. Goss, G.A.; Dyer, W.E. Physiological characterization of auxinic herbicide-resistant biotypes of kochia (Kochia scoparia). Weed Sci. 2003, 51, 839-844. [CrossRef]

33. Walsh, M.J.; Owen, M.J.; Powles, S.B. Frequency and distribution of herbicide resistance in Raphanus raphanistrum populations randomly collected across the Western Australian wheatbelt. Weed Res. 2007, 47, 542-550. [CrossRef]

34. Beckie, H.J.; Blackshaw, R.E.; Low, R.; Hall, L.M.; Sauder, C.A.; Martin, S.; Brandt, R.N.; Shirriff, S.W. Glyphosate- and acetolactate synthase inhibitor-resistant Kochia (Kochia scoparia) in Western Canada. Weed Sci. 2013, 61, 310-318. [CrossRef]

35. Tranel, P.J.; Riggins, C.W.; Bell, M.S.; Hager, A.G. Herbicide resistances in Amaranthus tuberculatus: A call for new options. J. Agric. Food Chem. 2011, 59, 5808-5812. [CrossRef]

36. Busi, R.; Powles, S.B. Cross-resistance to prosulfocarb and triallate in pyroxasulfone-resistant Lolium rigidum. Pest Manag. Sci. 2013, 69, 1379-1384. [CrossRef] [PubMed]

37. Petit, C.; Bay, G.; Pernin, F.; Délye, C. Prevalence of cross- or multiple resistance to the acetyl-coenzyme A carboxylase inhibitors fenoxaprop, clodinafop and pinoxaden in black-grass (Alopecurus myosuroides Huds.) in France. Pest Manag. Sci. 2010, 66, 168-177. [CrossRef] [PubMed]

(C) 2020 by the authors. Licensee MDPI, Basel, Switzerland. This article is an open access article distributed under the terms and conditions of the Creative Commons Attribution (CC BY) license (http://creativecommons.org/licenses/by/4.0/). 